\title{
足関節捻挫に対するアイシングが筋反応時間および 機能性パフォーマンスに及ぼす影響
}

\author{
李 虎 城 ${ }^{1)}$ 向井直樹 ${ }^{2)}$ 秋本崇之年 河野一 郎 ${ }^{2)}$
}

\section{EFFECT OF ICING TREATMENT ON MUSCLE REACTION TIME AND FUNCTIONAL PERFORMANCE OF A SPRAINED ANKLE}

\author{
Hoseong Lee, Naoki Mlkai, Takayuki Akimoto and Ichiro Kono
}

\begin{abstract}
【Objective】 The purpose of this study was to determine whether icing treatment has an effect on muscle reaction time and functional performance of a sprained ankle. 【Methods】 Subjects were six persons (healthy group) and six persons who had an acute ankle sprain (patient group). Anterior talar translation and talar tilt of the six patient group were evaluated by the stress $\mathrm{X}$-ray measure. Ice treatment was applied for 20 minutes. 【Results】 The following points were clarificd : 1) Reac. tion times of peroneus longus (PL) and peroneus brevis $(\mathrm{PB})$ for the sprained ankle group (SA) were significantly longer than those for the non-sprained ankle group (NA) $(p<0.05)$. Length of time of standing on one leg with closed eyes for SA was significantly shorter than for NA $(\mathrm{p}<0.05) .2)$ After icing treatment, reaction time of PL for SA tended to be shorter. Furthermore, PB significantly decreased after icing treatment $(p<0.05)$. Side-steps for SA were significantly increased after icing treatment $(p<0.05)$. 3) Reaction times of PL and PB for NA significantly increased after icing treatment $(p<0.05)$. Standing on one leg with closed eyes for NA significantly decreased after icing treatment $(\mathrm{p}<0.05)$. 【Conclusion】 It was shown that icing treatment of a sprained ankle leads to a shorter muscle reaction time and an increase in the number of side-steps. Therefore, it was concluded that icing treatment of a sprained ankle might be able to improve incapacitated neuromus. cular function and functional performance by acute trauma.
\end{abstract}

(Jpn. J. Phys. Fitness Sports Med. 2002, $51: 175 \sim 184$ )

key word : ankle sprain, icing treatment, peroneal reaction time, neuromuscular function, functional performance

\section{I．緒言}

アイシングはテーピングやストレッチ同様, ス ポーツ現場において最も浸透しているコンディシ ヨニングの方法の一つである。アイシングは主と してスポーツにおける外傷・傷害に対し, 疼痛と 腫脹を抑える目的で実施され，早期復帰のため のリハビリテーションへの移行に役立ってい $ろ^{1-3)}$.
アイシングによる病態生理学的影響には，筋温 の低下，代謝の低下，炎症への影響，血液循環へ の影響, 痛みの軽減, 筋スパズムの抑制, そして 組織のスティフネスの增大などが推察されてい $ろ^{2-8)}$.

これまでのアイシングに関する研究として, 軟 部組織や筋骨格系の急性外傷の際に行われる応急 処置 ${ }^{9 \sim 11)}$ とスポーツにおける傷害のリハビリ

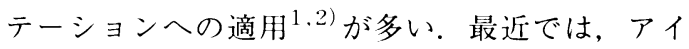

\footnotetext{
1) 筑波大学大学院 博士課程 人間総合科学研究科スポーツ医学専攻 テ305-8574 茨城県つくば甫天王台1-1-1

2) 筑波大学体育科学系 干 305-8574 茨城県つくば市天王台 1-1-1

3) 東京大学大学院総合文化研究科生命環境科学系 T 135-8902 東京都目黒区駒場3-8-1
}

Graduate School of Comprehensive Human Sciences, Doctoral Program of Sport Medicine. Tennodai, Tsukuba city, Ibaraki 305-8574

Institute of Health and Sport Sciences, University of Tsukuba. Tennodai, Tsukuba city, Ibaraki 305-8574

Department of Life Sciences, Graduate School of Arts and Sciences, The University of Tokyo, Komaba 3-8-1. Meguro, Tokyo 135-8902 
シングによる神経筋機能 ${ }^{5,12,13)}$ の変化に関して も報告がある。 Halar et al. ${ }^{12)}$ は，ヒトの脛骨神 経の伝導速度が $2 \sim 10^{\circ} \mathrm{C}$ の皮膚温の低下によって 直線的に隇少することを報告している，同様に， Heinz et al. ${ }^{18)}$, Halar et al. ${ }^{19)}$ は, 運動神経は温 度の低下に伴い伝導速度が低下し刺激に対する反 応が羊延すると報告している．固有知覚に対する アイシングが与える影響に関しては，影響をうけ $ろ^{20)}$ という報告とうけない21,22) とする報告があ り，一定した見解は得られていない。一方，アイ シングによる機能性パフォーマンスの変化につい ても報告がある ${ }^{5.7,14 \sim 17)}$. Cross et al. ${ }^{16)}$ は，ア イシングによって筋機能や筋収縮速度が低下し, その結果, 機能性パフォーマンスの低下をもたら すことを示している．吉松ら ${ }^{17)}$ は，寒冷療法に よる神経-筋パフォーマンスの低下を報告してい る。このように，アイシングが神経筋機能や機能 性パフォーマンスに及ほす影響については最近,

多くの報告があるが，これらはすべて健常人を対 象として用いた研究であり, 実際に急性損傷を対 するアイシングが神経筋機能および機能性パフ オーマンスに及ほす影響に関する研究はほとんど ない.

そこで本研究では, 受傷後一週間以内の足関節 捻挫を対象とし，アイシングが神経筋機能に及ほ す影響を検討することにした，足関節神経筋機能 の指標として突発的足関節内反刺激に対する長 · 短腓骨筋の反応時間を用い，さらに，足関節捻挫 に対するアイシングが運動動作中の運動能力にお ける機能性パフォーマンスに与える影響について も検討を加えた。

\section{II. 方法}

\section{A. 被験者}

被験者は, 捻挫群として急性足関節捻挫あるい
は，足関節捻挫による不安感を強く訴え，筑波大 学保健管理センターにおいて, 初診時 (受傷後 1 週間以内)に，ストレス用足関節固定器 Telos SE (Telos Japan 社製)を用い，距骨傾斜角と前方引 き出し距離を評価した者 6 名 (patient group; 男 子：4 名，女子：2)であった。非捻挫群は，下 肢障害, 神経学的障害のない者 6 名 (healthy group；男子：4名，女子：2)であった(Table 1). 被験者に本研究の目的および測定内容を説明 し, 研究参加の同意を得た.

\section{B． 実験プロトコルおよびアイシングの方法}

捻挫群の非捻挫足 (以下健側 ; nonsprained ankle) と捻挫足（以下患側； sprained ankle）および 非捻挫群の右足の筋反応時間と機能性パフォーマ ンステストはアイシング適用前に実施した (ice 前). 15分間の座位による安静の後, 捻挫群の捻 挫足 (患側の ice 直後) と非捻挫群の右足 (非捻挫 群の ice 直後)の足関節にアイシングを行い, 再 び筋反応時間および機能性パフォーマンステスト を実施した．捻挫群の健側と非捻挫群の左足はア イシングを行わずに20分間の安静を保った。アイ シング 24 時間後 $(24 \mathrm{~h}$ 後)に再び筋反応時間およ び機能性パフォーマンステストを行った．実験室 の室温は22度に設定した。

アイシングの方法はアイシングパック $\left(0{ }^{\circ} \mathrm{C}\right.$, $1.5 \mathrm{~kg})$ を足関節全体を覆うように直接当て (20分 間)，幅 $15 \mathrm{~cm}$ のバンデージで，できるだけ一定 の圧迫で巻き, 固定した.

\section{C. 筋反応時間 (足関節内反刺激による長・短 腓骨筋の反応時間)}

腓骨筋反応時間を測定するため，片側足関節に 対して, 重力による突発的内反ストレス刺激 (sudden ankle inversion stress)を模擬できるプラ

Table 1. Characteristics of subjedts.

\begin{tabular}{ccccc}
\hline group & Number & Age (years) & Height $(\mathrm{cm})$ & weight (kg) \\
\hline \hline patient group & 6 & $21.6 \pm 3.6$ & $165 \pm 8.1$ & $61.5 \pm 13.3$ \\
healthy group & 6 & $23.0 \pm 0.8$ & $167 \pm 5.5$ & $61.0 \pm 7.5$ \\
\hline
\end{tabular}

Values are Mean \pm SD 
ットホームを作成した。

腓骨頭から外顆までを結んだ直線の上から $1 / 3$ にあたる長腓骨筋 (peroneus longus, 以下 PL)に, また, 下から $1 / 3$ にあたる短腓骨筋 (peroneus brevis，以下 $\mathrm{PB}$ )にそれぞれ $2 \mathrm{~cm}$ 間隔で表面電 極(ディスポ電極・BIOPAC 社)を貼布した。電極 は体幹に対し近位側にプラス電極，遠位側にマイ ナス電極を貼布した。なお，不感電極は膝蓋骨中 央部に貼布した.

被験者をプラットフォームの上で両足に均等な 力が加わるように立たせた。このとき，両足はプ ラットフォーム上に記した直線の上に第二趾を置 き,踵部はその直線よりもやや外側に位置させた。 被験者に前方を向かせリラックスさせた後, 筋電 図による測定を開始した。続いて付属のスイッチ を押しプラットフォームを急激に $25^{\circ}$ 傾かせた ときの筋反応時間を測定した，スイッチを押した 時点を開始点，筋電波形の立ち上がりがみられた 時点を反応点とし，開始点から反応点までの時間 を筋反応時間とした（Fig. 1)。また，各被験筋に 対する筋反応時間の測定は 3 回とし，スイッチを
押すタイミングはランダムにした。実測値は 3 回 の平均とした.

筋電図はポータブルの MP100 (BIOPAC 社)を 使用し, 筋電波形は EMG100A (BIOPAC 社)より, 内反開始時の信号は ERS100A (BIOPAC 社)より 入力した。これらのシグナルをパーソナルコンピ ユーターに取り込み, 解析ソフト「Acqknowledge」 により得られた筋電図波形から筋反応時間を分析 した．電極の位置は油性ペンでしるしをつけてお き, $24 \mathrm{~h}$ 後 (24時間後)にも同様の位置で電極を 貼布できるようにした。

D. 機能性パフォーマンステスト

1. 閉眼片脚立ち

滑りにくい平らかな床の上で裸足になり, 両手 を腰におき，目を閉じて片足で立った姿勢を保持 させ，その保持時間を秒単位で計測した．最大時 間は(1)開眼した時点，(2)腰から手が離れた時点， (3)上げている足が床または支持足に触れた時点， (4)支持足が移動した時点のいずれかの条件までと した。測定はアイシングを適用した足から行い,

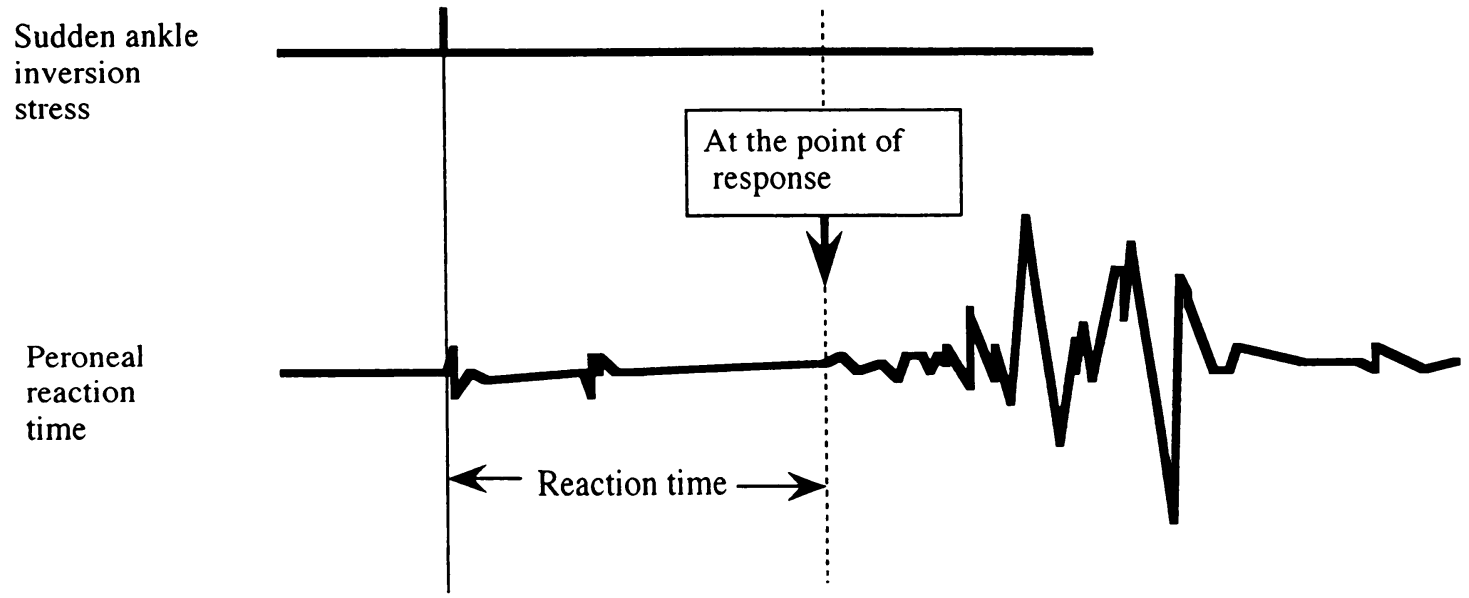

Fig. 1. Recording of peroneal reaction time.

Peroneal reaction times were recorded from the point of trapdoor tilting to the point of response. 
短い休息の後，もう一方の足について行った。こ れらの測定は振動および雑音のない状況で実施し た。

\section{2. サイドステップ}

中央をまたいだ状態から験者の開始合図ととも に一定の時間内に繰り返してサイドステップし， そのステップした回数を数えた。時間は 20 秒と し， $1.2 \mathrm{~m}$ 間隔で引かれた 3 本の平行線を足が越 えた，もしくは触れた時点を 1 回 (1 ステップ) と した。なおこの条件を満たさなかった場合は， 回数には数えないものとした。測定は 1 セットと し，滑りにくい平らかな床の上で裸足により実施 した.

\section{E. 統計処理}

測定値は全て平均值士標準偏差で表した。各測 定值の分析にはWilcoxon 符号付順位検定を用い た。有意水準は $5 \%$ を採択した。

\section{III. 結果}

\section{A．健側と患側による比較}

健側と患側による比較では，長・短腓骨筋反応 時間は患側に有意な遅延が認められた(Table 2, $\mathrm{p}<0.05)$. 例として，短腓骨反応時間の比較を Fig. 2 に示した。閉眼片足立ちでは患側に有意な 短縮が認められた (Table 2, p<0.05).

Table 2. Mean muscle reation times and functional performances before, after, $24 \mathrm{~h}$ after an application of icing for each condition.

\begin{tabular}{|c|c|c|c|}
\hline & \multicolumn{3}{|c|}{ Patient group } \\
\hline & before icing & after icing & $24 \mathrm{~h}$ after icing \\
\hline \multicolumn{4}{|c|}{ peroneus longus reation times (msec) } \\
\hline NA & $65.3 \pm 15.5$ & $65.8 \pm 19.8$ & $68.3 \pm 8.0$ \\
\hline \multicolumn{4}{|c|}{$\begin{array}{l}\text { SA } \\
\text { peroneus brevis reation times (msec) }\end{array}$} \\
\hline NA & $66.1 \pm 9.9$ & $68.9 \pm 14.6$ & $68.1 \pm 10.1$ \\
\hline $\begin{array}{l}\text { SA } \\
\text { standing on one leg wit }\end{array}$ & \multicolumn{2}{|c|}{ standing on one leg with closed eyes (sec) } & $75.8 \pm 11.8$ \\
\hline NA & $51.8 \pm 35.5$ & $64.0 \pm 26.0$ & $56.9 \pm 23.2$ \\
\hline SA & $14.7 \pm 7.7^{*}$ & $8.7 \pm 5.6$ & $13.5 \pm 2.4$ \\
\hline \multirow[t]{3}{*}{ side-steps(num ) } & $33.5 \pm 4.0$ & $35.5 \pm 3.8^{*}$ & $34.8 \pm 5.3$ \\
\hline & \multicolumn{3}{|c|}{ healthy group } \\
\hline & before icing & after icing & $24 \mathrm{~h}$ after icing \\
\hline \multicolumn{4}{|l|}{ peroneus longus } \\
\hline $\begin{array}{l}\text { reation times (msec) } \\
\text { peroneus brevis }\end{array}$ & $70.3 \pm 13.3$ & $77.5 \pm 5.2^{*}$ & $68.9 \pm 8.3^{*}$ \\
\hline reation times (msec) & $69.4 \pm 11.6$ & $78.1 \pm 11.3^{*}$ & $70.8 \pm 11.10^{*}$ \\
\hline $\begin{array}{l}\text { standing on one leg } \\
\text { with closed eyes (sec) }\end{array}$ & $30.2 \pm 21.3$ & $16.6 \pm 12.3^{*}$ & $32.2 \pm 25.10^{*}$ \\
\hline side-steps (num) & $43.3 \pm 4.1$ & $42.5 \pm 3.9$ & $44.2 \pm 2.5$ \\
\hline
\end{tabular}

NA non-spraind ankle; SAspraind ankle

$*: \mathrm{p}<0.05$, significant difference spraind ankle nonspraind ankle.

\# : p $<0.05$, significant difference before and after icing application. 


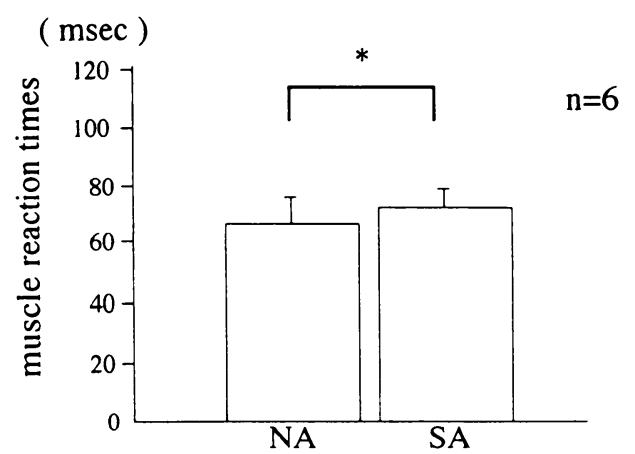

Fig. 2. Peroneus longus reation times (patient group).

Comparing of nonspraind ankle (NA) and spraind ankle $(\mathrm{SA})$. Values are the means $\pm \mathrm{SD}$ of 6 per. sons ${ }^{*}: \mathrm{p}<0.05$.

B．患側におけるアイシング前・後による比較 患側におけるアイシング前・後による比較で は，長腓骨筋反応時間はアイシング後に短縮する 傾向にあった。一方，短腓骨筋ではアイシング後 に有意な短縮が認められた (Fig. 3, p < 0.05)。閉 眼片足立ちではアイシング前・後に有意な差はな かった。サイドステップでは，アイシング後に有 意な増加が認められた(Table 2, $\mathrm{p}<0.05)$.

\section{C. 非捻挫群におけるアイシング前・後による 比較}

非捻挫群におけるアイシング前・後による比較 では，長・短腓骨筋反応時間ともにアイシング後

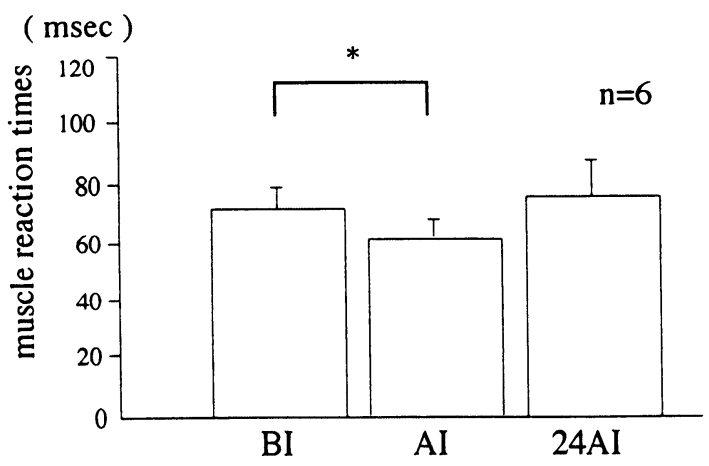

Fig. 3. Peroneus longus reation times (patient group).

Comparing of before (IB), after (IA), $24 \mathrm{~h}$ after (24 IA) an application of icing. Values are the means \pm SD of 6 persons ${ }^{*}: \mathrm{p}<0.05$.

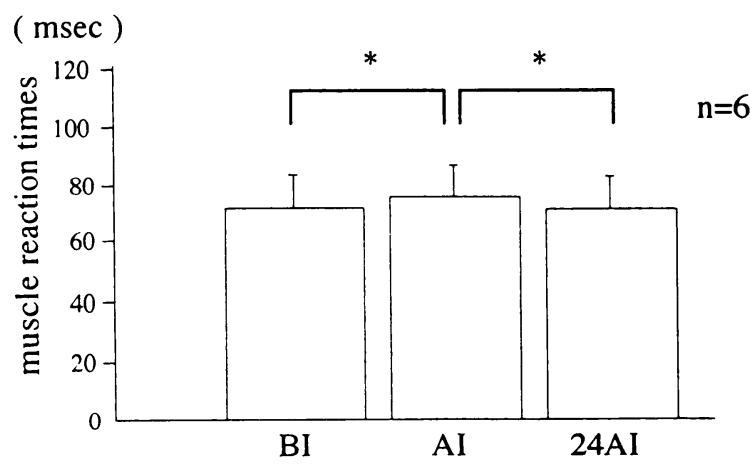

Fig. 4. Peroneus longus reation times (healthy group).

Comparing of before (BI), after (AI), $24 \mathrm{~h}$ after (24 AI) an application of icing. Values are the means \pm SD of 6 persons ${ }^{*}: \mathrm{p}<0.05$

に有意な遅延が認められた (Table 2, p < 0.05). 例として，短腓骨反応時間の比較を Fig. 4 に示 した。閉眼片足立ちではアイシング後に有意な短 縮が認められた (Table 2, p < 0.05)。 サイドステ ップではアイシング前・直後に変化はなかった.

\section{N. 考察}

これまで外傷・傷害に対するアイシングが神経 筋機能および機能性パフォーマンスに与える影響 を検討した報告はほとんどないため，本研究では 特に受傷後一週間以内の急性足関節捻挫を対象と し，アイシングが神経筋機能に及ぼす影響を検討 した。さらに，急性足関節捻挫に対するアイシン グが運動動作中の連動能力における機能性パフ オーマンスに与える影響についても検討を加え た.

\section{A. 健側と患側との比較}

足関節の中で腓骨筋は足関節外側傷害に対する 保護 (dynamic stabilizer) として働いていると考え られる ${ }^{23)}$. Lofvenberg et al. ${ }^{24)}$ は突然の変位に対 する足関節の固有知覚反応の遅延が足関節の外側 不安定性の素因または原因であると指摘してい る. 従って, 腓骨筋反応時間は足関節の機能的不 安定性を定量的評価する手段として有用であると 考えられる。

捻挫群の健側と患側の筋反応時間を比較する 
と，長・短腓骨筋ともに患側で有意な遅延が認め られた (Table 2, Fig. 1, p<0.05). Konradsen et al. ${ }^{25)}$ は足関節の機能的不安定性を訴える患者 15 名と不安定性のない15名を対象として足関節に突 発的内反ストレス刺激を加え, 短腓骨筋の反応時 間を測定したところ, 不安定群で筋反応時間の有 意な遅延がみられたと報告しており, 本研究と同 様の結果を示している. しかし, Konradsen らの 報告の中では，この突発的足関節内反刺激に対す る筋反応時間が損傷の結果として遅延する機序に ついては明確に考察されていない.

Johnson $\mathrm{M}$ et al. と Johnson C. ${ }^{26.27)}$ は足関節捻 挫による筋反応時間遅延の理由を三つ挙げ，第一 に伸張, 部分断裂, または完全断裂による足関節 の外側の関節包靫帯構造の機械的損傷, 第二に関 節の求心性固有受容器の損傷または機能的傷害, 第三に外反筋 (長・短腓骨筋)の筋力低下であると 推察しているが，それぞれに関する明確な指摘は されていない. 本研究のような突発的足関節内反 刺激を加えた場合, 筋紡錘が刺激を感知しその情 報は脊骾を上行し, 中枢に達する。そ後, 大脳 皮質からの指令により末梢の筋収縮が引き起こさ れると考えられる。本研究では足関節捻挫のため 筋紡錘からの情報入力の低下が生じ，筋反応時間 が遅延したことが考えられる．また筋紡錘以外の 勒帯や関節包に分布する神経終末であるメカノレ セプターが損傷され, 固有知覚が傷害を受けるこ とにより，神経一筋のコントロール不全が生じる というメカノレセプターの関与も考えられる. メ カノレセプターは，それぞれ特有の刺激に対して 足関節周囲筋の緊張を調節する動きがある。突発 的足関節内反刺激が加えられた瞬間に足関節周囲 の筋および勒帯，関節包は他動的に伸張および短 縮される，その伸張度合いの急激な変化により， 筋においては筋紡錘が伸張されることによる反射 が起こると同時に，関節包や靫帯においても急激 な伸張に伴うメカノレセプターからの反射が起こ る. その結果として, $\alpha$ 運動ニューロンが興奮し, それに対応した足関節周囲筋の収縮が行われた可 能性がある。

閉眼片足立ちはバランスを測定するテストの一
つであり，足関節に対する機能性不安定性の評価 に適した方法である ${ }^{28)}$. 本研究における捻挫群 の健側と患側の比較では，患側で有意な短縮が認 められた(Table 2, p <0.05). Brunt et al. ${ }^{28)}$ は, 足関節におけるバランスのコントロールは，主に 足関節固有受容器によるものであると報告してい る。また，末梢感覚は身体の静的姿勢維持に重要 であると述べている．本研究で観察された時間の 短縮は, これらの固有受容器や靶帯損傷によって 患側のバランス能力が低下したためと考えられ る.

\section{B．患側のアイシング前・後による比較}

捻挫群での患側の長腓骨筋反応時間はアイシン グ後に短縮する傾向にあり，短腓骨筋では有意な 短縮が認められた (Fig. 3，p<0.05)。 アイシング 後に長・短腓骨筋の反応時間が短縮した原因の一 つとして，アイシングによって固有受容器の増幅 率が増加したことが考えられる ${ }^{29.30)}$.つまり, アイシングにより固有受容器が活性化し, 刺激に 対する反応が早まったと考えられる. Roland et al. ${ }^{29)}$ は筋の能動的収縮に伴う kinesthesia と受動 的収縮に伴う kinesthesia として区別している。

運動感覚の基礎となる感覚は深部の関節, 筋およ び腱に分布する受容器からの情報に基づく感覚で ある.この感覚に関与する受容器は固有受容器と もいわれ，ルフィニ小体，パチニ小体，ゴルジ小 体, 自由神経終末などの関節受容器, 筋紡錘, ゴ ルジ腱等の腱受容器の受容器があると言われてい る. 本研究において捻挫群の患側の筋反応時間に 遅延がみられたことは, 上記の関節受容器あるい は腱受容器のどこかに障害を有している可能性が 考えられる. 本研究では, 足関節捻挫として勒帯 を中心とした関節内メカノレセプター，または筋 紡錘からの情報入力の低下, 中枢からの運動指令 の何らかの抑制がアイシング適用によって改善し た可能性が考えられる。しかしながら，本実験系 では関節周囲軟部組織のメカノレセプターや筋紡 錘もしくは，末梢神経系に対して中枢からの抑制 が反映されたのか，それぞれの関与の割合に関し ては不明のままであり,これらの考察に関しても 
あくまで可能性を示唆したにすぎない. 今後，そ れぞれのレセプターに関して生理学的な実験系に より研究を行う必要がある.アイシングによって 筋反応時間が短縮したもう 1 つの原因として, 疼 痛の軽減による可能性が考えられる。坂根 ${ }^{30)}$ は 足関節不安定性を有する運動選手に足関節足根洞 部を局注し, 疼痛を除去することによって遅延し ていた反応時間が有意に改善したと報告してい る.このことは, 我々の推察を支持していると考 えられる.

患側の閉眼片足立ちでは, アイシング前・後に 有意な差はなかった. Tropp et al. ${ }^{31)}$ は捻挫の既 往があるサッカー選手群と既往のないサッカー選 手群のアイシング前・後にバランス能力を比較し たところ，変化がないことを報告している．Ingersoll et al. ${ }^{21)}$ は足関節に対するアイシングはバ ランス能力に影響しないと報告している。このよ うに，多くの研究者によってアイシングがバラン ス能力に影響を与えないことを報告しており ${ }^{32)}$, 本研究と同様の結果を示している.

患側のサイドステップでは，アイシング後に有 意な増加が認められた (Table 2, p<0.05). 疼痛 は筋力, 柔軟性, パワー,そしてスピード発揮を 抑制させると言われている3)。本研究では, アイ シングによって疼痛の軽減が生じ, パフォーマン スを向上させた可能性が考えられる。

\section{C. 非捻挫群におけるアイシング前・後による 比較}

非捻挫群の筋反応時間では長・短腓骨筋 (Fig. 2)ともにアイシング後に有意な羊延が認められた (Table 2, p<0.05). 神経と神経の機能的な接合 部はシナプスと呼ばれ，シナプス伝達は組織温度 の低下によって減少すると報告されている33.34). Foldes et al. ${ }^{33)}$ は筋温を $37^{\circ} \mathrm{C}$ から $17^{\circ} \mathrm{C} に$ 低下させ たときに前シナプスにおけるアセチルコリンの放 出が $60 \%$ 以上減少したことを示している．上述の 報告と同様, 本研究でも, 組織温度の低下によっ て各シナプス間に何らかの抑制が働き，反応時間 が遅延した可能性が考えられる。

非捻挫群の閉眼片足立ちではアイシング直後に
有意な短縮を示し (Table 2, p < 0.05)，先行研究 の報告と必ずしも一致しない。本研究で用いた非 捻挫群は，主にスポーツを行っていない対象であ るため，アイシングに慣れておらず，心理的な不 安，恐怖などにより思うようなパフォーマンスが 発揮できなかったと考えられる。また，組織温度 の低下は皮虐からの入力や筋紡錘の感受性を減ず $3^{35)}$ という報告もあり，温度の低下とともにバ ランスをコントロールする能力が低下したため, 保持時間が短縮したとも推察できる.

非捻挫群のサイドステップではアイシング前・ 後で変化はなかった. Knight et al. ${ }^{36)}$ は足関節と 腓腹筋のアイシングでは敏捷性テストに影響を与 えなかったと報告している，おそらく，組織温度 低下に伴い，筋力発揮が低下する分を動員する運 動単位の増加により補うのであろうと述べてい る. Kenneth と Todd A et al. ${ }^{3,16)}$ はアイシング後 に筋肉が冷やされたときや激しい運動が要求され るとき敏捷性は低下したと報告している。また, Davied と Young. ${ }^{20.37)}$ は筋収縮速度と筋力発生 能力は冷却によって減じると報告している. 本研 究では, 非捻挫群における敏捷性はアイシング適 用によって影響を受けないことが確認された。

\section{V. 結語}

本研究では, 足関節捻挫に対するアイシングが 筋反応時間および機能性パフォーマンスに及ぼす 影響について検討し，以下の知見を得た。

足関節捻挫におけるアイシング施行によって筋 反応時間の短縮, サイドステップの増加を認めた。 従って,アイシング施行は急性外傷による神経筋 機能および機能性パフォーマンスの低下を改善す る可能性が示唆された。

\section{謝 辞}

本研究遂行にあたりご指導いただいた筑波大学大学 院博士課程医学研究科 赤萩 博氏に深く抒礼申し上 げます。

(受理日 平成13年11月30日) 


\section{参文献}

1) Boland, A. L. Rehabilitation of the injured athlete. Am. J. Sports Med., (1979), 5, 226-234.

2) Swenson, C., Sward, L., Karlson, J. Cryotherapy in sports medicine. Scand. J. Med. Sci. Sports, (1996). 6, 193-200.

3) Kenneth, L. K., (田淵健一訳), Cryotherapy in sport injury management. Sportsmedicine Quarterly, ブッ クハウス・エイチディ, 東京, (1997).

4) Foldes, C. F., Kuze, S.. Deery, A. The influence of temperature on neuromuscular performance. J. Neural. Transmission, (1978), 43, 27-45.

5) Rantanen, J., Hurme, T., Kalimo, J. H. Effects of early cryotherapy in experimental skeletal muscle muscle injury. Scand. J. Med. Sci. Sports, (1993), 3, 46-51.

6) Palmer, J. C., Knight, K. L. Ankle and thigh skin surface temperature changes with repeated ice pack application. J. Athletic Training, (1992), 27, 138.

7) 山本 利春, 運動後のアイシンの効果を測る〜クー リングダウンとしてのアイシングがパフォーマン スに及ぼす影響, Training Journal, (1998), 19, 7679 .

8) Sherwin, S. W., Marc, N. C., Robert, K., Allen, B. R. Theeffects of ice blood flow and bone metabolism in knees. Am. J. Sports Med., (1994), 22, 537-540.

9) Sherwin, S. W., Richard, L. I., Richard, W. M., Peter, J. T., Malcolm, D. C., Bruce, R. Comparison of various icing times in decreasing bone metabolism and blood Flow in the knee. Am. J. Sports Med., (1995), 23, 74-76.

10) Glen, A. G. Therapeutic heat and cold for athletic injuries. Physician Sportsmed, (1990), 18, 87- 94.

11) Matsen, F. A., Questad, K., Matsen, A. L. The effect of local cooling on postfracture swelling. Clin. Orthop. (1975), 109, 201-206.

12) Halar, E. M., DeLisa, J. A., Brozovich, F. V. Nerve conduction velocity relationship of skin subcutaneous intramuscular temperatures. Arch. Physician Med. Rehabil., (1980), 61, 199-203.

13) Mary, B. C., Lowell, B. S. Electromyographic response of peroneal muscles in surgical and nonsurgical injured ankles during sudden inversion. J. Athletic Training. (1993), 18, 497-501.

14) Auvo, K., Pekka, M. A performance test protocol and scoring scale for the evaluation of ankle injuries. Am. J. Sports Med., (1994), 22, 463-469.

15) Kevin, M. C., Rick, W. Functional performance following an ice immersion to the lower extremity. J. Athletic Training, (1996), 31, 113-116.

16) Todd, A. E., Kenneth, L. K., Cross, K. M. Agility following the applic ation of cold therapy. J. Athletic Training, (1995), 30, 231-234.

17）吉松俊紀, 斉藤明義, 佐藤賢治, 阿部健男, 相原 利男, 秋元良美, 上原マリ子, 小林由香, 龍順之助, 寒冷療法が神経-筋パフォーマンスに与える影響,
日本整形外科スポーツ医学会雑誌, (1999), 19, 180.

18) Heinz, L., Wilfried, A., Albert, G. Neuromuscular properties and functional aspects of taped ankles. Am. J. Sports Med., (1999), 27, 69-75.

19) Halar, E. M., Delia, J. A., Soine, T. L. Nerve conduction studies in upper extremities : skin temperature corrections. Arch. Physician Med. Rehabil., (1983), 64, 412-416.

20) Gerig, B. K. The effects of cryotherapy upon ankle proprioception. J. Athletic Training, (1990), 25, 119.

21) Ingersoll, C. D., Knight, K. L., Merrick, M. A. Sen sory perception of the foot and ankle following ther. apeutic application of heat and cold. J. Athletic Training, (1992), 27, 231-234.

22) Lareviere, J., Osternig, L. R. The effect of ice on joint position sense. J. Sports Rehabil., (1994), 3, 58-67.

23) Claude, H., Laurent, M., (井原秀俊, 中山彰一訳). 膝・足関節・足部の新しい神経-運動器協調訓練 : Proprioceptive exercise の実際, 医苗薬出版, 東京, (1985).

24) Lofvenberg, R., Karrholm, J., Sundelin, G., Ahlgren, $O$. Prolonged reaction time in patients with chronic lateral instability of the ankle. Am. J. Sports Med., (1995), 23, 414-417.

25) Konradsen, L., Bohsen, R. J. Prolonged peroneal reaction time in ankle instability. Int. J. Sports Med., (1993), 12, 290-292.

26) Johns, R. J., Wright, V. Relative importance of various tissues in joint stiffness. J. Appl. Physiol., (1962), 17, 824-828.

27) John, W. F. Effect of an ankle orthosis and ankle ligament anesthesiaon ankle joint proprioception. Am. J. Sports Med., (1994), 22, 648-653.

28) Martin, B., Thomas, H. Ankle orthoses effect on single-limb standing balance in athletes with func. tional ankle instability. Arch. Physician. Med. Rehabil., (1998), 79, 939-944.

29) Roland, P. E., Ladegard, P. H. A quantitative analysis of sensations of tension and kinesthesia in man. Brain, (1977), 56, 671-692.

30) 坂根正孝, 足関節不安定性を有する運動選手の腓骨 筋反応時間, 日本足の外科学会誌，(1995)，16，283284.

31) Tropp, H., Odenrick, P., Gillquist, J. Stabilometry recordings in functional and mechanical instability of the ankle joint. Int. J. Sports Med., (1985), 6, 180182.

32) Lareviere, J., Osternig, L. R. The effect of ice on joint position sense. J. Sports Rehabil., (1994), 3, 58-67.

33) Foldes, F. F., Kuze, S., Vizi, E. S., Deery, A. The in fluence of temperature on neuromuscular performance. J. Neural Transmission, (1978), 43, 27-45.

34) Thornton, R. J., Blakeney, C., Feldman. S. A. The effects of hypothermia on neuromuscular conduc- 
tion. British J. Aesthetics, (1976), 48, 264.

35) Moberg. E. The role of cutaneous afferents in position sense, kinesthesia, and motor function of the hand. Brain, (1983), 106, 1-19.

36) Knight, K. L., Ingersoll, C. D., Trowbridge, C. A. Cordovia, M. L., Hyink, K. L., Welch, S. M. The effects of cooling the ankle, the triceps surae, or both on functional agility. J. Athletic Training. (1994), 29, 165.

37) Lareviere, J., Osternig, L. R. The effect of ice on joint position sense. J. Sports Rehabil., (1994), 3 , 58-67. 